ЕНЕРГЕТИКА. ТЕПЛОТЕХНІКА.

\title{
STRUCTURAL OPTIMIZATION OF STATIC POWER CONTROL PROGRAMS OF NUCLEAR POWER PLANTS WITH WWER-1000
}

\begin{abstract}
С.О. Кокол. Структурна оптимізація статичних програм регулювання потужності АЕС з ВВЕР-1000. Розглядається питання можливості перемикання програм регулювання потужності AЕC з BВEР-1000. Мета: Метою даної статті $\epsilon$ визначення найкращої програми регулювання потужності енергоблока при циклічній добовій зміні енерговироблення, а також здійснення їх перемикання. Матеріали і методи: Розглянута задача пошуку найкращої програми регулювання належить до класу задач багатокритеріальної оптимізації. Експлуатація ядерної енергоустановки моделювалася за такими програмами регулювання потужності енергоустановки з постійною середньою температурою теплоносія, з постійним тиском в другому контурі, з постійною температурою на вході в ядерний реактор. Результати: Запропоновано цільову функцію, яка складається з трьох нормованих критеріїв: глибини вигоряння палива, ступеня руйнування оболонок тепловиділяючих складань, а також значення зміни потужності. Після моделювання роботи ядерної енергоустановки протягом всієї іії кампанії було отримано значення обраних критеріїв, які підставлялися в цільову функцію. Мінімальне з трьох значень цільової функції визначало ознаку перемикання розглянутих статичних програм регулювання потужності ядерної енергоустановки в залежності від програми регулювання потужності в поточний момент часу.

Ключові слова: програма регулювання, цільова функція, критерій, багатокритеріальна оптимізація.

E.O. Kokol. Structural optimization of static power control programs of nuclear power plants with WWER-1000. The question of possibility the power control programs switching for WWER-1000 is considered. Aim: The aim of this research is to determine the bes program for the power control of nuclear reactor under cyclic diurnal behavior of electrical generation, as well as the switching implementation. Materials and Methods: The considered problem of finding the best control program refers to the multicriteria optimization class of problems. Operation of the nuclear power generation system simulated using the following power control programs: with constant average temperature of transfer fluid, with constant pressure in the reactor secondary circuit, with constant temperature in input of the nuclear reactor. Results: The target function was proposed. It consists of three normalized criteria: the burn up fraction, the damage level of fuel rod array shells, as well as changes in the power values. When simulation of the nuclear power generation system operation within the life was done, the values of the selected criteria were obtained and inserted in the target function. The minimum of three values of the target function depending on the control program at current time defined the criterion of switching of considered static power control programs for nuclear power generation system.

Keywords: WWER-1000, NPP, control program, target function, multicriteria optimization
\end{abstract}

Introduction. At night in the united energy system of Ukraine there is an overproduction of electricity which can not be reduced by exploitation reason of the nuclear power plants (NPP) in the basic version and because of an insufficient number of pumped storage power plants (PSPP). Due to this fact it is advisable to transfer the nuclear power plants operation from the basic mode schedule of electric load in semi peak, reducing the capacity of the nuclear power unit at the time of the failure load of up to $80 \%$ and increasing it up to the nominal value with a scheduled speed in the remaining time of the day.

DOI 10.15276/opu.3.47.2015.07

(C) 2015 The Authors. This is an open access article under the CC BY license (http://creativecommons.org/licenses/by/4.0/). 
Today the exploitation of nuclear reactors in the cyclic operation can be performed using one of the three control programs: with constant average temperature $\left(T_{\mathrm{av}}=\right.$ const $)$, with constant pressure in the second circuit $\left(P_{2}=\right.$ const $)$ [4], with constant temperature at the entrance to the nuclear reactor $\left(T_{\text {in }}=\right.$ const $)$ [2]. Each control program has its advantages and disadvantages. Analysis of sources $[1 \ldots 4]$ allowed to systematize the strengths and weaknesses of the control programs, the results of which are shown in Table 1.

Table 1

Control programs advantages and disadvantages

\begin{tabular}{|c|c|c|}
\hline $\begin{array}{c}\text { Program's } \\
\text { name }\end{array}$ & Advantages & Disadvantages \\
\hline$T_{\mathrm{av}}=\mathrm{const}$ & $\begin{array}{l}\text { - favorable for the } 1^{\text {st }} \text { circuit equipment due to } \\
\text { the stable temperature conditions; } \\
\text { - the possibility of using the temperature ef- } \\
\text { fect to regulate the reactor reactivity; } \\
\text { - operating speed, ease of automation. }\end{array}$ & $\begin{array}{l}\text { - increasing the steam pressure in the steam } \\
\text { generator from the second circuit while reduc- } \\
\text { ing the power unit (deterioration of the strength } \\
\text { characteristics). } \\
\text { - xenon oscillations emergence; } \\
\text { - a large number of unbalanced water; } \\
\text { — input-output of solid absorber leads to a } \\
\text { curvature of the energy release field; } \\
\text { - motion control rods up at border movement } \\
\text { in fuel claddings, located near the control rods } \\
\text { because of the jump in power, there are signifi- } \\
\text { cant voltage. }\end{array}$ \\
\hline$P_{2}=$ const & $\begin{array}{l}\text { - favorable for the } 2^{\text {nd }} \text { circuit equipment; } \\
\text { - the possibility of using higher steam parame- } \\
\text { ters before the turbine at nominal mode; } \\
\text { - operating speed, ease of automation. }\end{array}$ & $\begin{array}{l}\text { - change in the average temperature of the } \\
\text { coolant limits the unit maneuverability capabili- } \\
\text { ties and complicates the working conditions of } \\
\text { the pressure automatic control program in the } \\
\text { compensator volume; } \\
\text { - necessity in resizing pressurizer towards } \\
\text { increase; } \\
\text { — increased thermal stresses in the reactor ves- } \\
\text { sel, fuel claddings; } \\
\text { - an impact on the control rods is required to } \\
\text { compensate the changes in reactivity due to } \\
\text { temperature effect which leads to a distortion of } \\
\text { the field energy release; } \\
\text { - a large number of unbalanced water; } \\
\text { - xenon oscillations emergence; } \\
\text { - motion control rods up at border movement } \\
\text { in fuel claddings, located near the control rods } \\
\text { because of the jump in power, there are signifi- } \\
\text { cant voltage. }\end{array}$ \\
\hline$T_{\text {in }}=$ const & $\begin{array}{l}\text { - the stability of the nuclear reactor due to the } \\
\text { stable axial offset; } \\
\text { - minimization of the control rods; } \\
\text { - minimum consumption of pure distillate and } \\
\text { boron concentrate; } \\
\text { - reduced amount of unbalance waters; } \\
\text { - improving the working conditions of fuel; } \\
\text { - the possibility of using temperature effect } \\
\text { for controlling the reactivity of the nuclear reac- } \\
\text { tor; } \\
\text { - parameters of power distribution adjustment } \\
\text { height with changes in power do not vary; } \\
\text { - the absence of xenon oscillations. }\end{array}$ & $\begin{array}{l}\text { - large time integration; } \\
\text { - a small control range is limited by permissi- } \\
\text { ble pressure in the steam generator; } \\
\text { - inlet temperature of the coolant in the reactor } \\
\text { increases with increasing pressure in the main } \\
\text { steam collector is strictly limited by the permis- } \\
\text { sible modes table; } \\
\text { - there is a cyclic variation of the } 2^{\text {nd }} \text { circuit } \\
\text { parameters; } \\
\text { - low speed. }\end{array}$ \\
\hline
\end{tabular}


The aim of this research is to determine the best program for the power control of WWER-1000 reactor under cyclic diurnal behavior of electrical generation, as well as the switching implementation. The best program will be determined according to the current values of fuel burn-up $B$, the damage degree of the fuel element cladding $w$ and the power change $\Delta N$ NPP from the desired value during the day taking into account the time for a complete fuel assemblies (FA) burn-up.

Materials and Methods. According to the sources [1..4] the advantages and disadvantages of the control programs were identified. Such a systematic organization of the information has shown that the choice of the necessary control program under varying process parameters can be reduced to the solution of the multicriteria optimization problem.

On the basis of multicriteria decision-making problems, on the assumption of the classical method of operations research, this article is dedicated to the description of the third stage of solving any problem in operations research, namely finding the optimal solution. To find the best control program the multicriteria task is considered to determine the minimum of the target function of each of the power control programs NPP for their further switch. Therefore, to solve the optimization problem a target function $\mathrm{J}$ was formulated. It combines normalized following criteria: the values of fuel burn-up $B$, the values of the damage degree of the fuel element cladding $w$, and also the power change $\Delta N$ NPP from the nominal value. These criteria were chosen from [5], where the control programs were compared.

Using the model of the nuclear reactor [6] in Simulink (Matlab) the proposed criteria for the further simulation switch control programs were calculated that allow to make the structural optimization.

The problem under consideration of searching for the best control program refers to the class of multicriteria optimization. To join the components into one functional it was proposed to use the method of targeted programming. Thus in general form the functional can be written as follows:

$$
\begin{gathered}
J=\sqrt{\alpha_{1} B^{2}+\alpha_{2} w^{2}+\alpha_{3} \Delta N^{2}} \\
\alpha_{1}+\alpha_{2}+\alpha_{3}=1,
\end{gathered}
$$

where $\alpha_{1}, \alpha_{2}, \alpha_{3}$ - the weighting coefficients.

The initial data for the burn-up model were obtained in [5]. Analysis of these data revealed no clear relationship between the burn-up and the control program. Later it was suggested to consider not the absolute values $B(\tau)$, but to approximate the dependence $\Delta B(\tau)$ by a simple third degree polynomial, given in the Table 2 .

The general view of the polynomial that defines the burn-up depth is as follows:

$$
y=a_{1} x^{3}+a_{2} x^{2}+a_{3} x
$$

Burn-up is calculated for each FA from the first to the fourth year of their useful life as follows:

$$
B_{1}=B_{11}+\Delta B \cdot t,
$$

where $\quad B_{1}$ - the current burn-up value;

$B_{11}-1$ st year burn-up fuel assemblies;

$\Delta B$ - polynomial burn-up value;

$t-10$ minutes step time.

After calculating the burn-up values of the FA from the first to fourth year of their useful life, normalization for the following maximum values was presented in Table 3.

Table 2

Table 3

The values of polynomials coefficients in calculating burn-up

\begin{tabular}{c|c}
\hline$a_{1}$ & $-0,000000000077$ \\
\hline$a_{2}$ & 0,000000049703 \\
\hline$a_{3}$ & $-0,000020486677$ \\
\hline
\end{tabular}

Maximum values $B$ that depend on the year of their operation

\begin{tabular}{c}
\hline$B_{1}{ }^{\max }=23$ \\
$B_{2}{ }^{\max }=44$ \\
\hline$B_{3}{ }^{\max }=56$ \\
\hline$B_{4}{ }^{\max }=56$
\end{tabular}


Consequently, the final burn-up value was put in the target function, obtained as:

$$
B=\sqrt{\left(B_{1} / B_{1}^{\max }\right)^{2}+\left(B_{2} / B_{2}^{\max }\right)^{2}+\left(B_{3} / B_{3}^{\max }\right)^{2}+\left(B_{4} / B_{4}^{\max }\right)^{2}} .
$$

There are four types of fuel assemblies in the nuclear reactor. They are characterized by the year of their useful life. Initial data for the mathematical model of the destruction of fuel rod cladding [4] adopted the following:

$$
w_{1}=0, w_{2}=0,096, w_{3}=0,308, w_{4}=0,469 .
$$

At the end of each year a permutation of the FAs is fulfilled. The FAs that have worked for four years are withdrawn. In their place the FA of the third year of service are rearranged. The FAs that spent two years in the reactor core are rearranged in place for the third year service. One-year FAs take place of the biennial ones. Fresh FAs are placed on the site for the first year. To select an optimal control program at the current time is necessary to evaluate the performance of the nuclear reactor in each of the three programs. Let $w_{i j}$ is a predicted value for the FAs $j$-th year while operating the $i$-th program.

Then, in the general case, the damage degree of the fuel element cladding calculation is represented in (6)

$$
w_{i j}=w_{i}+\Delta w_{i j} \cdot \Delta t
$$

where $\Delta w_{i j}$ - maximum change of the damage degree of the fuel element cladding value afterl day $j$-th year assemblies while operating the $i$-th program.

Then the current value of the cladding destruction was calculated and was introduced into the formula for calculating the target function:

$$
W_{1}=\sqrt{\left(1-w_{11}\right)^{2}+\left(1-w_{12}\right)^{2}+\left(1-w_{13}\right)^{2}+\left(1-w_{14}\right)^{2}}
$$

where $w_{11}$ is damage degree of the fuel element cladding while operating the $1^{\text {st }}$ program and the $1^{\text {st }}$ year assemblies;

$w_{12}$ is damage degree of the fuel element cladding while operating the $1^{\text {st }}$ program and the $2^{\text {nd }}$ year assemblies;

$w_{13}$ is damage degree of the fuel element cladding while operating the $1^{\text {st }}$ program and the $3^{\text {rd }}$ year assemblies;

$w_{14}$ is damage degree of the fuel element cladding while operating the $1^{\text {st }}$ program and the $4^{\text {th }}$ year assemblies.

The change of NPP power $\Delta N$ is carried out by weekly cycle unloading the nuclear reactor. The NPP operates at $100 \%$ capacity from Monday to Friday during the day from 6 a.m. to 10 p.m., and from 10 p.m. to 6 a.m. at $80 \%$ capacity. The cycle power change was chosen because it coincides with the schedule of the night unloading grid.

Results. Thus the simulation results namely the changes in the value of the target function $J$ are shown in Figure 1.

Below is a generalized scheme of a NPP that includes automation elements regarding to the three possible control programs.

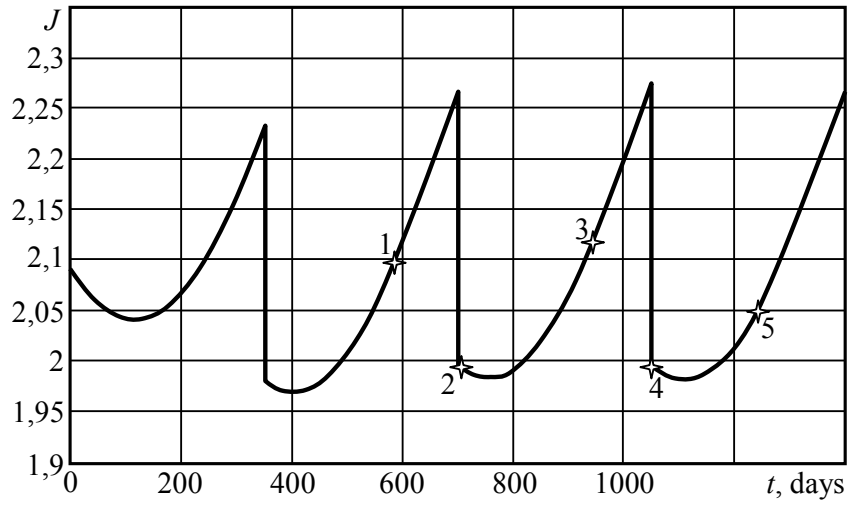

Fig. 1. Diagram changes in the values of the target function: 1 - control program switching moment from $T_{a v}$ to $T_{i n}$; 2 - control program switching moment from $T_{\text {in }}$ to $T_{a v}$; 3 - control program switching moment from $T_{a v}$ to $T_{i n}$; 4 - control program switching moment from $T_{\text {in }}$ to $T_{a v}$; 5 - control program switching moment from $T_{a v}$ to $T_{\text {in }}$ 
There is also a switching scheme that shows what to turn on while operating the NPP at one of three control programs.

Table 4

Scheme of power unit control program. Switching

\begin{tabular}{|c|c|c|c|}
\hline & $T_{\mathrm{av}}=\mathrm{const}$ & $P_{2}=$ const & $T_{\mathrm{in}}=\mathrm{const}$ \\
\hline$\frac{1}{2}$ & \multicolumn{3}{|c|}{ in operating condition } \\
\hline 3 & turned on & turned on & turned on \\
\hline 4 & \multirow{3}{*}{\multicolumn{3}{|c|}{ in operating condition }} \\
\hline 5 & & & \\
\hline 6 & & & \\
\hline 7 & turned on & turned on & \\
\hline 8 & turned on & turned on & \\
\hline 9 & turned on & turned on & turned on \\
\hline 10 & turned on & & turned on \\
\hline 11 & turned on & & \\
\hline 12 & & turned on & \\
\hline 13 & turned on & turned on & turned on \\
\hline 14 & & & turned on \\
\hline 15 & turned on & turned on & turned on \\
\hline 16 & & turned on & \\
\hline 17 & & turned on & \\
\hline 18 & turned on & & \\
\hline 19 & turned on & & turned on \\
\hline 20 & turned on & & \\
\hline 21 & turned on & turned on & \\
\hline 22 & turned on & & \\
\hline 23 & & & turned on \\
\hline 24 & & & turned on \\
\hline 25 & & & turned on \\
\hline 26 & & & turned on \\
\hline
\end{tabular}

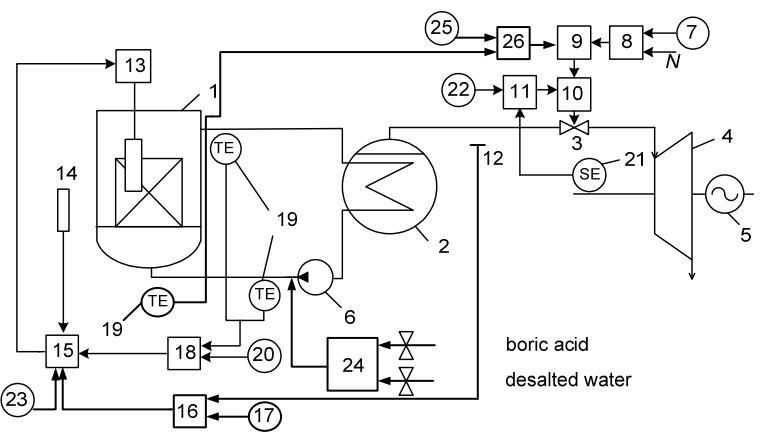

Fig. 2. Generalized schematic diagram of NPP, where 1 —nuclear reactor; 2 - steam generator; 3 - turbine control valves; 4 -turbine; 5 - generator; 6 - the main circulating pump; 7 - setting mechanism for the generator electric power; 8 - reactor-power regulator; 9 - turbine control mechanism; 10 - servomotor; 11 turbine-speed regulator; 12 — transducer vapor pressure in the $2^{\text {nd }}$ circuit; 13 - control rod drive; 14 -ionization chamber; 15 — reactor neutron-power regulator; 16 regulator of steam pressure in the $2^{\text {nd }}$ circuit; 17 - setting mechanism for steam pressure in the $2^{\text {nd }}$ circuit, $18-a v-$ erage temperature of the coolant regulator 1st circuit; 19 - coolant temperature sensor 1st circuit; 20 — setting mechanism for average coolant temperature of the 1st circuit, 21 — turbine speed sensor, 22 — setting mechanism for the turbine rotational speed, 23 — setting mechanism for axial offset; 24 — tank boost pumps; 25 — setting mechanism for coolant temperature at the inlet to the corrosion protection of the nuclear reactor; 26 — regulator of the coolant temperature at the inlet to the reactor core

Conclusions. Therefore, this article shows the results of the research. It can be concluded that the goal is reached. Specifically, it can be possible to switch one control program to a better one according to the selected criterion during the reactor campaign for 5 times. Moreover, the control programs change will reduce the damage of the fuel cladding.

\section{Література}

1. Методика сравнения долговечности оболочек твэлов, работающих в переменном режиме / М.В. Максимов, С.Н. Пелых, О.В. Маслов, В.Е. Баскаков // Вопросы атомной науки и техники. Физика радиационных повреждений и радиационное материаловедение. — 2009. — № 4-2. — С. $192-197$.

2. Пат. 100070 Україна, MПК G21C 7/00. Спосіб управління ядерною енергетичною установкою 3 реактором водяного типу при зміні потужності реактора або зовнішнього навантаження / Максимов М.В., Баскаков В.Е, Пелих С.М., Цисельська Т.О.; заявник та патентовласник Максимов М.В., Баскаков В.Е, Пелих С.М., Цисельська Т.О. — № a201102326; заявл. 28.02.2011; надр. 12.11.2012, Бюл. № 21 . 
3. Метод оценки эффективности алгоритма маневра мощностью энергоблока с реактором типа ВВЭР / М.В. Максимов, С.Н. Пелых, О.В. Маслов, В.Е. Баскаков // Известия ВУЗов. Ядерная энергетика. - 2008. - № 4. - С. $128-139$.

4. Ustinov, A.N. VVER-1000 load-follow conditions simulation / A.N. Ustinov, K.Yu. Kurakin, A.K. Gorokhov // Proceedings of the $17^{\text {th }}$ Symposium of Atomic Energy Research (AER'2007), 23-29 September 2007, Yalta, Ukraine. — Budapest: KFKI Atomic Energy Research Institute, 2007. — Vol. II. - PP. $817-823$.

5. Кокол, Е.А. Оптимальное управление мощностью ВВЭР-1000 за счет целевого выбора программы регулирования / Е.А. Кокол // Автоматика-2015: Матеріали 22-ї Міжнародної конференції з автоматичного управління, м. Одеса, 10-11 вересня 2015 р. - Одеса: ТЕС, 2015. - С. 119 - 120.

6. Максимов, М.В. Модель реактора ВВЭР-1000 как объекта управления / М.В. Максимов, К.В. Беглов, Т.А. Цисельская // Современные технологии управления [в 2 т.]. Т. 1.: монография / под общ. ред. С.В. Куприенко; SWorld. - Одесса: Куприенко С.В., 2012. — С 108 - 122.

\section{References}

1. Maksimov, M.V., Pelykh, S.N., Maslov, O.V., \& Baskakov, V.E. (2009). Durability comparison procedure for fuel-element claddings working in varying operating modes. Problems of Atomic Science and Technology: Physics of Radiation Effect and Radiation Materials Science, 4, 192-197.

2. Maksymov, M.V., Pelykh, S.M., Baskakov, V.Ye., \& Tsyselska, T.O. (2012). Method for controlling nuclear plant with water-cooled reactor upon changing reactor power or external load. Ukraine Patent: UA 100070.

3. Maksimov, M.V., Pelykh, S.N., Maslov, O.V., \& Baskakov, V.E. (2008). A method to estimate efficiency of a nuclear power unit capacity maneuver algorithm for the case of WWER reactors. Proceedings of Universities. Nuclear Power, 4, 128-139.

4. Ustinov, A.N., Kurakin, K.Yu., \& Gorokhov, A.K. (2007). VVER-1000 load-follow conditions simulation In I. Vidovszky (Ed.), Proceedings of the $17^{\text {th }}$ Symposium of Atomic Energy Research (AER'2007) (Vol. II, pp. 817-823). Budapest: KFKI Atomic Energy Research Institute.

5. Kokol, E.A. (2015). Optimal control of WWER-1000 power by target selection of the regulation program. In M.V. Maksimov (Ed.), Proceedings of the XXII International Conference on Automatic Control (Automatics-2015) (pp. 119-120). Odessa: TES.

6. Maksimov, M.V., Beglov, K.V., \& Tsiselskaya, T.A. (2012). Model of WWER-1000 reactor as a control object. In S.V. Kupriyenko (Ed.), Modern Control Technologies (Vol. 1, pp. 108-122). Odessa: S.V. Kupiyenko. 